\title{
Relationship between Linear Combination of Variables in Retort Processing of Palmyra Palm Tender Fruit Endosperm (Borassus flabellifer)
}

\author{
S. K. Mathanghi ${ }^{*}$, S. Kanchana ${ }^{2}$, V. Perasiriyan ${ }^{1}$, G. Hemalatha ${ }^{2}$, \\ C. Vanniarajan ${ }^{3}$, K. Kumutha ${ }^{3}$ and A. Karthiayani ${ }^{1}$ \\ ${ }^{1}$ College of Food and Dairy Technology, Tamil Nadu Veterinary and Animal Sciences \\ University, Chennai, India \\ ${ }^{2}$ Community Science, ${ }^{3}$ Agricultural, College and Research Institute, Tamil Nadu Agricultural \\ University, Madurai, India \\ *Corresponding author
}

\section{A B S T R A C T}

Keywords

Palmyra palm, Retort processing

Article Info

Accepted:

10 November 2020

Available Online:

10 December 2020
Linear regression model was determined to establish relation pertaining to solid (Palmyra palm tender fruit endosperms) to liquid (sugar syrup) ratio in a standard sized metalized retort pouches. Also it was optimized that 2:3 ratio was best suited with less processing time and proportionate weights of different thickness. Shelf life study results showed that there was a commercial sterility over the storage period and test for Clostridium, Salmonella and Staphylococcal Spp. was negative till end of study period. This relationship model may reduce the efforts on experimenting each time with Palmyra palm tender fruit endosperm.

\section{Introduction}

Palmyra palm (Borassus flabellifer) is the consumed by South-east Asian countries and considered celestial tree named as karpaha tree since each and every part of the tree can be utilized. Evidence of the use of Borassus flabellifer sugar in India has been reported by the Greek historian Megasthenes, ambassador to the court of Chandragupta, in the $4^{\text {th }}$ century BC (first day of $400 \mathrm{BC}$ and ended the last day of $301 \mathrm{BC}$; Before Christ). The Palmyra Palm have protected the water table, helps the birds and animals ecosystem, (Alaguraj, 2017) and dependable on the facet of climate change crisis. Palmyra palm is one of the major plants available in our native yielding non seed carbohydrates from peduncles of inflorescence. Palmyra palm Tender Fruit Endosperm (PTFE) is having stomachic, sedative, laxative and aphrodisiac properties in nature that are useful in hyperdipsia, dyspepsia, flatulence trouble, skin diseases, hemorrhages, fever and general debility (Jerry, 2018) and still practiced as folk medicine. Minimal utilization of this fruit 
in spite of marvelous health potential in regular culinary use is that, they are not be either quantified or standardized through nutritional surveys and other means of scientific validations, needed for the usage intensification in household diets and diversification across the regions and cultures.

The soft jelly like endosperm obtained from the tender fruit of Palmyra is highly perishable and seasonal. Postharvest treatments, packaging and storage conditions significantly increases the shelf life of any product and hence it becomes necessary to find the better the treatment conditions, storage parameters and packaging materials to increase the shelf life of processed PTFE. With this perspective, this research is proposed to find an appropriate technology to extend the shelf life with minimal loss of nutrients and to uplift its economic value.

Application of thermal processes will create inquisitive industrialist to pierce the production of this product and helps in entering to export avenues, especially retort processing. To achieve the sterile conditions, retort and canning industries overcook the food batches to ensure the commercial sterility and always excessive heating decreases the quality and underestimates the plant capacity. In appropriate proportion of product and medium increases redundant mishap to the final shape of the product though the temperatures were stick on.. A unified model to find the cold point temperature wherein, retort temperature, percentage solid content and initial process conditions and ingredients were considered independent variable and they found that the predicted model values of temperature profile matched with $\pm 10 \%$ error and their model (Gokhale and Lele, 2014).

Sometimes over-processing may lead to steam over-consumption that has a serious impact on production cost in larger run (Featherstone 2015). Therefore, thermal processing should be optimized in terms of solid to liquid medium to minimize energy consumption and reduce the number of trials on the same product.

\section{Materials and Methods}

\section{Retort processing}

Palmyra palms were purchased from local vendor from Tiruvallur district, in the outskirts of Chennai, Tamil Nadu, India. Every time PTFE were purchased from same region to prevent biasedness due to geographical variation. Completely filled fruit, that are sparkling and crystal-clear, 80 to $90 \%$ maturity were selected and subjected to retort process immediately or within 24 hours of procurement. Procured fruits were prewashed and then removed the peel using a hand knife and given second wash prior processing. Indigenously manufactured retort pouches were purchased. Palmyra palm tender fruit endosperm was measured 4.8 to $4.9 \mathrm{pH}$ values and it falls under low acidic fruit category. For low acid foods pressures setting of $10-15$ psi were usually preferred to prevent overcook. Time to reach the process temperature is called come up time (CUT). Process time of the product depends on many factors and usually from end of CUT to commencement of cooling. During cooling the steam is turned off and water was added to retort to prevent overdo of heating. Sealed pouches were loaded in the trays and lid along with gasket was closed. Trapped air must be removed before processing to maintain the air pressure through steam. This process is called venting after which temperature and pressure gauge reading should be noted (in this experiment venting time was 30 seconds). Selection of retortable pouch laminates permit less chances to overcook and had better colour, texture and less nutrient loss. Heat 
processing of Palmyra palm Tender Fruit Endosperms was experimented with nontransparent 4 layered retort pouches at $121.1^{\circ} \mathrm{C}$ temperature and 15 psi pressure for 20 minutes using water spraying type of retort having a capacity of 100 packs per batch and The processing time was determined as per the method of Gopal et al., (2001).

\section{Standardization of sugar strength}

Standardization of sugar strength was first done using different concentrations of sugar syrup i.e. $40^{\circ}, 45^{\circ}, 50^{\circ}$ and $55^{\circ} \mathrm{Bx}$ sugar syrup (1 degree Brix $\left[{ }^{\circ} \mathrm{Bx}\right]=1 \mathrm{~g}$ of sucrose $/ 100 \mathrm{~g}$ of solution) and tested with Palmyra Palm Tender Fruit Endosperm in 1:1 ratio in retortable pouches. Organoleptic evaluations of the prepared products were performed using 9 point hedonic scale rating $(1=$ dislike extremely; $5=$ neither like nor dislike; $9=$ like extremely) with 20 semi-trained panelists (Lawless and Heymann, 2010, Sang-Oh et al, 2013).

\section{Product parameters}

Weight of sugar solution and weight of solid particles (PTFE) inserted in grams unit and approximate thickness of the PTFE were taken as independent variables and the time taken to reach the coldest point taken as dependent variable. Thickness of the slender PTFE was $1.5 \mathrm{~cm}$ (approx) and slightly larger and firmer endosperm was $2.5 \mathrm{~cm}$ (approx). Many combinations of solid PTFE to liquid sugar syrup medium were tested in different ratios in the pack with dimension of $200 \mathrm{~mm}$ $\times 150 \mathrm{~mm}$ having filling capacity of $300 \mathrm{gms}$ and thickness. Required number of pouches was fitted with glands and thermocouples and it was inserted into PTFE center and sealed using O-ring valves and studied for heat penetration. In this study, the average initial temperature of the product used was $35.5 \pm$ $0: 1^{\circ} \mathrm{C}$ and the come-up time for retort were
$12-14$ minutes. Heat penetration test was conducted using the thermocouples. Sterility was expressed as an $\mathrm{F}_{0}$-value were determined using general method given in (Holdsworth and Simpson, 2016), as in

$$
F O=\int_{0}^{t} 10^{T-T_{\text {ref }} / z} \mathrm{dt},
$$

Where $F 0$ is the heat required for the commercial sterilization process, which is expressed as the equivalent heating time (in minutes) at a constant temperature of $121.1^{\circ} \mathrm{C}$ to inactivate Clostridium botulinum spores. $T$ is the temperature at any given time; Tref is a reference processing temperature $\left(121.1^{\circ} \mathrm{C}\right.$ or $250^{\circ} \mathrm{F}$ ), and $z$-value is $10^{\circ} \mathrm{C}$.

\section{Microbial analysis}

Standardized PTFE for retort processing was further observed for storage studies. Microbial analysis were done that are appropriate for low acid retort products such as, total viable counts, Clostridium Spp., Staphylococcus, salmonella and Yeast and mold count (Nalini et al., 2018). Real time shelf life analysis was also conceded for 180 days of storage during which microbiological evaluations also supported that the product was safe for consumption. Standard protocol mentioned were followed (FSSAI). All the data obtained were analyzed statistically using SPSS software (version 20.0)

\section{Results and Discussion}

The processed PTFE retort pouches were subjected organoleptic evaluations after 15 days of processing to have a uniform effect. 6 pouches of same sugar strength were opened at the time of evaluation and consensus attributes required were, the colour should be white translucent; texture like soft and slimy with sweet taste; and shape retaining Curving notch at the bottom and a sharp dome like tip 
at the top. Sensory evaluation was conducted in a sensory evaluation room by a trained 20 member panel using 9 point hedonic scale. From the table 1 it was evident that PTFE with $45^{\circ} \mathrm{Bx}$ were most liked by most semi trained panelists and taken for further studies. A non-parametric test (Joshi et al., 2017) for statistical evaluation using SPSS was performed.

Table.1 Standardization of sugar concentration for retort process of Palmyra palm Tender Fruit Endosperm (PTFE)

\begin{tabular}{|l|c|c|c|c|l|}
\hline Sensory parameters & $\begin{array}{l}\text { PTFE with } \\
\mathbf{4 0}^{\circ} \mathbf{B x}\end{array}$ & $\begin{array}{l}\text { PTFE with } \\
\mathbf{4 5}^{\circ} \mathbf{B x}\end{array}$ & $\begin{array}{l}\text { PTFE with } \\
\mathbf{5 0}^{\circ} \mathbf{B x}\end{array}$ & $\begin{array}{l}\text { PTFE with } \\
\mathbf{5 5}^{\circ} \mathbf{B x}\end{array}$ & $\chi^{2}$ \\
\hline Colour and & $7.35 \pm 0.93$ & $8.00 \pm 0.85$ & $6.05 \pm 0.88$ & $5.45 \pm 1.67$ & $40.175^{* *}$ \\
Appearance / shape & $(50.50)$ & $(61.53)$ & $(26.65)$ & $(23.33)$ & \\
\hline Flavour & $7.05 \pm 0.99$ & $7.65 \pm 0.81$ & $6.20 \pm 1.34$ & $6.15 \pm 1.8$ & $14.65^{* *}$ \\
& $(41.89)$ & $(54.63)$ & $(30.28)$ & $(33.30)$ & \\
\hline Taste & $7.05 \pm 0.99$ & $7.95 \pm 1.05$ & $6.20 \pm 1.50$ & $6.15 \pm 1.4$ & $19.947^{* *}$ \\
& $(42.28)$ & $(58.25)$ & $(31.58)$ & $(29.90)$ & \\
\hline Texture & $7.55 \pm 0.75$ & $7.75 \pm 0.91$ & $6.75 \pm 1.3$ & $6.8 \pm 1.36$ & $9.793^{*}$ \\
& $(46.90)$ & $(49.33)$ & $(32.15)$ & $(33.63)$ & \\
\hline Overall acceptability & $7.60 \pm 0.59$ & $7.90 \pm 0.78$ & $6.4 \pm 1.3$ & $6.2 \pm 1.8$ & $22.484^{* *}$ \\
& $(48.80)$ & $(55.00)$ & $(29.30)$ & $(28.90)$ & \\
\hline
\end{tabular}

*Significant at 5\% level of significance $(\mathrm{p} \leq 0.05) ; \mathrm{n}=20$; Data are mean and S.D; within parenthesis mean ranks are given

Table.2 Relationship between linear combination of variables in retort processing of PTFE

\begin{tabular}{|l|r|r|r|r|r|}
\hline Variables & \multicolumn{2}{|c|}{$\begin{array}{c}\text { Unstandardized } \\
\text { Coefficients }\end{array}$} & $\begin{array}{c}\text { Standardized } \\
\text { Coefficients }\end{array}$ & \multicolumn{1}{c|}{$\begin{array}{c}\text { t } \\
\text { value }\end{array}$} & \multirow{2}{*}{ P value } \\
\cline { 1 - 4 } & \multicolumn{1}{|c|}{ B } & Std. Error & \multicolumn{1}{|c|}{ Beta } & & \\
\hline (Constant) & 7.538 & 0.688 & & 10.962 & $<0.001^{* *}$ \\
\hline X1 & 0.045 & 0.002 & 0.974 & 21.191 & $0.000^{* *}$ \\
\hline X2 & 0.688 & 0.296 & 0.107 & 2.324 & $0.031^{*}$ \\
\hline
\end{tabular}
a. Dependent Variable: time
b. Predictors: (Constant), X1=PTFE solids, $\mathrm{X} 2=$ Thickness of PTFE
c. $* * 1 \%$ level of significance; $* 5 \%$ level of significance

Table.3 The impact of storage on the nutritional quality of PTFE

\begin{tabular}{|c|c|c|c|c|c|}
\hline \multirow{2}{*}{ Parameters } & \multicolumn{4}{|c|}{ Impact of storage on the nutritional quality of PTFE } & \multirow{2}{*}{ F value } \\
\cline { 2 - 5 } & $\mathbf{0}^{\text {th }}$ day & $\mathbf{6 0}^{\text {th }}$ day & $\mathbf{1 2 0}^{\text {th }}$ day & $\mathbf{1 8 0}^{\text {th }}$ day & \\
\hline Moisture $(\%)$ & $86.98 \pm 0.95$ & $85.29 \pm 1.15$ & $83.59 \pm 0.93$ & $79.94 \pm 0.8$ & $42.458^{* *}$ \\
\hline Crude protein $(\mathrm{g})$ & $0.88 \pm 0.023$ & $0.87 \pm 0.023$ & $0.87 \pm 0.015$ & $0.88 \pm 0.019$ & $0.174^{\text {Ns }}$ \\
\hline Crude fiber $(\mathrm{g})$ & $0.88 \pm 0.01$ & $0.88 \pm 0.12$ & $0.84 \pm 0.01$ & $0.78 \pm 0.02$ & $72.39^{* *}$ \\
\hline Fat $(\mathrm{g})$ & $0.08 \pm 0.01$ & $0.08 \pm 0.01$ & $0.08 \pm 0.0$ & $0.08 \pm 0.01$ & $0.33^{\text {NS }}$ \\
\hline Total ash $(\mathrm{g})$ & $0.96 \pm 0.05$ & $1 \pm 0.0$ & $0.98 \pm 0.04$ & $0.98 \pm 0.05$ & $0.615^{\mathrm{NS}}$ \\
\hline
\end{tabular}

Data are mean and SD;*Significant at $5 \%$ level of significance, ** Significant at $1 \%$ level of significance 


\section{Regression analysis}

Relationship between the variables on the time required to reach the coldest point was ascertained. Model reveals that R (multiple correlation coefficient value) was 0.980 and that measures the degree of relationship between the time to reach cold spot and predicted values. $\mathrm{R}$ square i.e., coefficient of determination was 0.960 that depicts $96 \%$ of variation in time to reach cold spot was explained by the variation in independent variables. Adjusted $\mathrm{R}$ square value was 0.69457 and it was based on number of independent variables in a model. That is the desired property of a goodness of fit statistic. Durbin-Watson statistic was 2.604 and no auto correction was required. $F$ value in ANOVA was 227.225 and $\mathrm{P}$ value $<0.0001^{\mathrm{b}}$ (values was significant at $1 \%$ level). A multiple linear regress model was determined is given below based on table 2 .

$y=7.538+0.045 X 1+0.688 X 2$

Sugar solution added in the package found as percentage with PTFE for 300 grams and it was taken as excluded variable. Using this linear model least time taken to reach the cold spot was found 14.9 minutes in $1.5 \mathrm{~cm}$ thickness PTFE in 2: 3 ratio (i.e $120 \mathrm{~g}$ PTFE: $180 \mathrm{~g}$ Sugar solution). Similarly in same ratio with $2.5 \mathrm{~cm}$ PTFE thickness took 15 minutes. The proportion of solid as per minimal weights of standard weights and measurements were taken into account for packaging.

This linear equation were calculated and it is applicable for various ratio of solid to liquid medium in a 3D slab shaped pouches with a filing capacity of $300 \mathrm{gm}$ for PTFE. This projected model developed could be successfully extrapolated to predict heat penetrations studies. From this experiment solid to liquid ratio of 2: 3 was selected to get efficient average cold point reach temperature in about 15 minutes and have appropriate solid for perfect immersion into liquid medium and to have minimum solids presence in the consumer preferred portion size for this package.

\section{Nutritional quality of stored PTFE}

Nutritional parameters such as moisture percentage, protein, fibre and fat were analysed at regular time intervals till 180 days of storage and results are given in table 3 . From the table it was evident that there was a slight decrease in the moisture content, it may be due to osmosis from PTFE to liquid medium. In terms of protein, fat and total ash it remains the same. There was no visible change in terms of product when standard operating procedures of cut out analysis (usually done for thermally processed foods) were done on regular time interval of 60 days months till 180 days. The barrier properties of retort packaging material plays a major role in keeping quality of finished product substantiated by Yedle et al, (2020) on the significance of effect of packaging material that extended the shelf life of guava fruits.

\section{Microbial evaluation of standardized PTFE}

Microbial studies were conducted over a period of 180 days. Total viable count at $35^{\circ} \mathrm{C}$ should be less than $10^{7}$ per gram and that Salmonella should be detected in not less than one of five, $25 \mathrm{~g}$ samples of (Sampling-forMicrobiological-Analysis-Principles-andSpecific-Applications-ICMSF.1986.). Result showed absence of Salmonella, Clostridium and Staphylococcus in the PTFE samples throughout the study period. Bacterial numbers of $3.0 \log _{10}$ colony forming units $(\mathrm{cfu}) / \mathrm{cm}^{2}$ may be regarded as indication of good hygiene or of an efficient commercial operation (Shankar et al., 2002). Karthiayani et al., (2014) developed a mini retort and 
analysed its efficiency by processing three products namely milk, sweet corn and vegetable kurma and they stored the samples at room temperature and evaluated for shelf life and found meager differences in nutritional parameters. Palmyra palm products generally have large number of aerobic mesophils due to its sugar content. During tapping, fermentation and storage of palm sap, lactic acid bacteria, yeasts, and acetic acid bacteria were predominantly found (Nwachukwu et al., 2006) and this has showed in total viable counts. The impact of storage on the microbial load of the standardized PTFE showed the total viable counts increase from $0.45 \pm 0.02$ on $0^{\text {th }}$ day to $0.51 \pm 0.02$ on $60^{\text {th }}$ day, $0.48 \mathrm{~b} \pm 0.02$ on $120^{\text {th }}$ day and $0.47 \pm 0.02$ on $180^{\text {th }}$ day.

In conclusion the relationship between the variables depicted that change in ratio of solid to liquid along with thickness were established and it had a definite impact on the time of processing. Retort processed PTFE were stored for 180 days in room temperature without any physical damage and microbial contamination. Using the multiple linear model, best proportion of solid to liquid taken was $2: 3$ for $300 \mathrm{gm}$ filling capacity packs. Ratio had a lesser heat processing time been found thereby reduced processing time was achieved by attaining the high efficiency in accomplishing thermal death time quickly. The microbial analysis showed absence of Salmonella, Clostridium and Staphylococcal counts. This retort process has definitely enhanced the shelf life (storage) of the produce and seemingly gives an appealing sense to the consumers who always think of quality and safety.

\section{References}

Alaguraj, M. 2017. Need and importance of conservation of palmyra palm, the state tree of Tamil Nadu. International
Journal of Modern trends in Engineering and Science 04, 62-63.

Featherstone, S. 2015. A complete course in canning and related processes. Volume 3 Processing Procedures for Canned Food Products, $14^{\text {th }}$ edition, Woodhead Publishing.

Gokhale, S. V. and S.S. Lele. 2014. Retort process modelling for Indian traditional foods. J Food Sci Technol., 51, 31343143.

Gopal, T. K. S., P.K. Vijayan, K.K. Balachandran, P. Madhavan and Iyer, T.S.G. 2001. Traditional Kerala style fish curry in indigenous retort pouch. Food Control, 12, 523-527 (2001).

Holdsworth, S. D. and R. Simpson. 2016. Heat Penetration in Packaged Foods: In Thermal Processing of Packaged Foods, 161-195 Springer International Publishing.

Jerry, A. 2018. A Comprehensive Review on the Medicinal Properties of Borassus flabellifer. Journal of Academia and Industrial Research, 7(7).

Joshi, H., A. Kochhar, A and Boora, R.S. 2017. Organoleptic and Nutritional Evaluation of Value Added Products Developed from New Varieties of White and Pink-Fleshed Guavas. Chem Sci Rev Lett, 6(24), 2108-2113.

Karthiayani, A., D. Baskaran, D. Ramasamy, and Sivakumar, T. 2014. Low Cost Mini Retort for Small Scale Food Processing. National Seminar on "Education and Research Perspectives for Current and Future Trends in the Indian Meat Industry".

Lawless, H. T. and Heymann, H. 2010. Sensory Evaluation of Food. Principles and practices. $2^{\text {nd }}$ Edition, New York, Springer.

Nalini, P., J.J.R. Abraham, V.A Rao, R. N. Babu, T.N. Rajkumar, R. Rajkumar and Kathiravan, R.S. 2018. Shelf-Life of Ready-To-Eat Retort Processed Pepper 
Chicken. Int.J.Curr.Microbiol.App.Sci., 7, 832-840.

Nwachukwu, I.N., V.I. Ibekwe, R.N. Nwabueze and Anyanwu, B.N. 2006. Characterisation of palm wine yeast isolates for industrial utilization. African Journal of Biotechnology, 5. No. 19 1725-1728.

Sampling for microbiological analysis principles and specific applications ICMSF. 1986. Second edition ICMSF Blackwell Scientific Publications, 2nd ed. Toronto: University of Toronto Press.

Sang-Oh, P, P.R. Chae-min, P. Byung-Sang and Jong, H. 2013. The meat quality and growth performance in broiler chicken fed diet with cinnamon powder. $J$. Environ. Biol, 34, 127-133

Shankar, C. N. R., T.K.S. Gopal and Vijayan, P.K. 2002. Studies on heat processing and storage of seer fish curry in retort pouches. Packaging Technology and Science, 15, 3-7

Yedle, V.H., V.L, Kanawade, G.B, Yenge, N.N. Gaikwad, R.N. Kenghe and Shelar, S.D. 2020. Studies on shelf life extension of guava ( $\mathrm{Cv}$ Sardar) using different packaging materials. J.Environ.Biol, 41, 247-254.

\section{How to cite this article:}

Mathanghi, S. K., S. Kanchana, V. Perasiriyan, G. Hemalatha, C. Vanniarajan, K. Kumutha and Karthiayani, A. 2020. Relationship between Linear Combination of Variables in Retort Processing of Palmyra Palm Tender Fruit Endosperm (Borassus flabellifer). Int.J.Curr.Microbiol.App.Sci. 9(12): 1099-1105. doi: https://doi.org/10.20546/ijcmas.2020.912.132 